\title{
Atopic dermatitis. Interdisciplinary diagnostic and therapeutic recommendations of the Polish Dermatological Society, Polish Society of Allergology, Polish Pediatric Society and Polish Society of Family Medicine. Part I. Prophylaxis, topical treatment and phototherapy
}

\author{
Roman J. Nowicki ${ }^{1}$, Magdalena Trzeciak ${ }^{1}$, Maciej Kaczmarski², Aleksandra Wilkowska ${ }^{1}$, Magdalena Czarnecka-Operacz ${ }^{3}$, \\ Cezary Kowalewski ${ }^{4}$, Lidia Rudnicka ${ }^{5}$, Marek Kulus ${ }^{6}$, Agnieszka Mastalerz-Migas ${ }^{7}$, Jarosław Peregud-Pogorzelski ${ }^{8}$, \\ Małgorzata Sokołowska-Wojdyło', Radosław Śpiewak', Zygmunt Adamski³, Joanna Czuwara ${ }^{5}$, \\ Monika Kapińska-Mrowiecka ${ }^{10}$, Andrzej Kaszuba ${ }^{11}$, Dorota Krasowska ${ }^{12}$, Beata Kręcisz ${ }^{13}$, Joanna Narbutt ${ }^{11}$, \\ Sławomir Majewski ${ }^{14}$, Adam Reich ${ }^{15}$, Zbigniew Samochocki ${ }^{5}$, Jacek Szepietowski ${ }^{16}$, Katarzyna Woźniak ${ }^{4}$

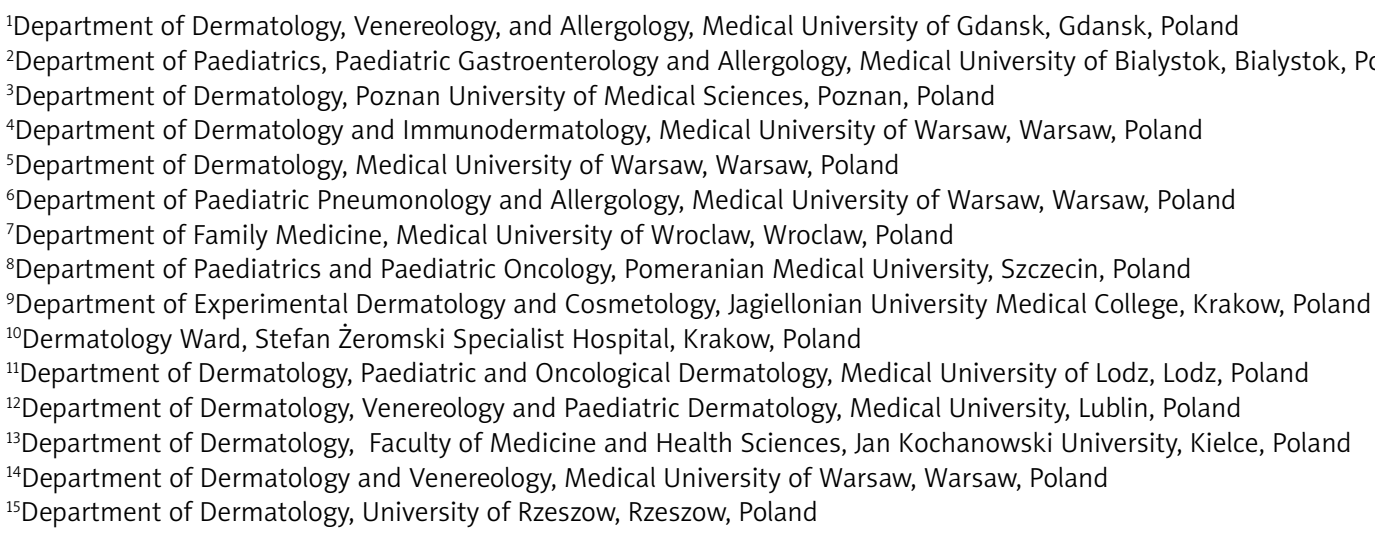

\begin{abstract}
Atopic dermatitis is a chronic and recurrent inflammatory dermatosis with concomitant intensive pruritus, and is diagnosed both in children and adults. Atopic dermatitis-patients are predisposed to have bacterial, viral and fungal skin infections; they also suffer from an increased risk of developing food allergies (especially, at an infantile age), allergic rhinitis, or bronchial asthma (a so-called atopic march). Currently, an increasing atopic dermatitis incidence constitutes a serious medical problem that regards not only dermatology and allergology, but also paediatrics, and family medicine. The basis for atopic dermatitis treatment and prophylaxis is restoration of epidermal barrier functions by means of tailored emollients. Atopic dermatitis therapies should effectively eliminate clinical symptoms of the disease, prevent exacerbations as well as complications, and improve patients' quality of life.
\end{abstract}

Key words: atopic dermatitis, allergic march, elimination diet, emollients, topical glucocorticoids, topical calcineurin inhibitors, proactive therapy, wet dressings therapy, wet dressings.

The article was published in the journal "Dermatology Review/Przegląd Dermatologiczny" 2019, 106, 354-371, DOI: https://doi.org/10.5114/dr.2019.88253.

Address for correspondence: Prof. Roman J. Nowicki MD, PhD, Department of Dermatology, Venereology, and Allergology, Medical University of Gdansk, 17 Smoluchowskiego St, 80-214 Gdansk, Poland, phone: +48 5858440 10, e-mail: rnowicki@gumed.edu.pl Received: 18.08 .2019 , accepted: 1.09.2019. 


\section{Introduction}

\section{Atopic dermatitis}

Atopic dermatitis (AD) is a common chronic recurrent non-infectious inflammatory disease that most often appears in early childhood and may persist for life. The disease is characterized by periods or exacerbations and remissions. The main symptoms include: intense pruritus and skin dryness, erythematous inflammatory skin lesions with eczematous morphology; chronic phase of the disease involves thickening (lichenization) and exfoliation of the epidermis. Patients tend to suffer from recurrent bacterial, viral and fungal skin infections. The lesions are most often form on the bends of elbows and knees, on the face and neck, but they may also cover the skin of the entire body (erythroderma). The site of exanthemata is age-related. Atopic dermatitis is a result of complex genetic, epigenetic, environmental and immunological interactions with a concomitant epidermal barrier defect [1, 2].

During the first years of life, $A D$ incidence is similar in both sexes; after the age of 6 , prevalence of the female sex over male is noted $(3: 2)[3,4]$. Atopic dermatitis usually starts in early childhood. It is believed that in $45 \%$ of infants symptoms appear before the $6^{\text {th }}$ month of life, and in 50\% before they are $1 \mathrm{y} / \mathrm{o}$. In $40-80 \%$ of children the disease tends to recede before the age of 5 , and in $20 \%$ of patients it is present till adulthood. In one out of four adult AD-patients, the disease develops de novo $[5,6]$. Large cities in Poland have been experiencing an increase in $A D$ incidence. The $A D$ incidence percentage among children ranges from 4.7 to $9.2 \%$, and among adults from $0.9 \%$ to $1.4 \%$ [7].

Chronic course of the disease and continual pruritus significantly decrease the quality of life of patients and their families, and lead to serious socio-economic consequences. Sleep disorders, absence at school and work, and social isolation may be the reasons behind depression, and even suicidal thoughts.

\section{Allergic march}

Atopic dermatitis may be concomitant with other IgE-dependent atopic diseases: bronchial asthma, allergic upper respiratory congestion and catarrhal conjunctivitis, and sometimes even food allergies. Epidemiological studies and clinical observations indicate the existence of a specific sequence of occurrence of atopic diseases. This phenomenon was called an allergic march and does not always have a classic course. About $34 \%$ of AD-patients develop allergic rhinitis, $20-35 \%$ asthma, and $15 \%$ - clinical symptoms of food allergies. Genetic factors and external factors such as stress, eating habits, infections, cigarette smoke, or smog, mainly predispose individuals to develop an allergic disease and allergic march $[1,2]$.

\section{Treatment - general recommendations}

An increase in $A D$ incidence constitutes a serious medical and therapeutic problem that regards not only dermatology and allergology, but also paediatrics and family medicine $[1,2,8-10]$. While commencing the AD treatment, not only should patient's age and site of skin lesions be taken into account, but also intensity of the inflammation (Table 1), and concomitant diseases, including: infections, contact allergy, food allergy, eye diseases, mental diseases, obesity, and cardiovascular diseases [810]. Contact eczema is confirmed in about $50 \%$ of children with initial diagnosis of $A D[11,12]$.

Special scales are used to objectively measure the intensity of skin lesions in AD [13]. SCORAD (Scoring Atopic Dermatitis) has been recognized to be the most reliable tool to measure clinical symptoms of $A D$ - together with EASI (Eczema Area and Severity Index) [13, 14]. SCORAD allows for assessing the area of involved skin, and the intensity of particular skin symptoms (dryness, erythema, oedema, effusion, erosions, lichenization) on a point scale from 0 to 3. Moreover, SCORAD includes the assessment of subjective symptoms: sleep disorders and pruritus intensity from 0 to 10; the assessment is provided by the patient. It is available for physicians as a computer or smartphone application. The scale facilitates treatment monitoring and objectivizing treatment results. The PO-SCORAD (Patient-Oriented Scoring Atopic Dermatitis) version based on SCORAD was created for patients. It correlates well with SCORAD, and correlates better with other scales that assess quality of life (e.g. DLQI) $[13,15]$. It is available as a convenient computer or smartphone application (https://www.poscorad.com/\#/poscorad/ pl). The application allows patients to assess the intensity of the disease themselves, and track its intensity; it also reminds the patients to use emollients, and sends information to physicians during the period between appointments. By introducing elements of self-assessment, treatments are more effective and less costly, while patients' quality of life is improving [16].

EASI scale allows for assessing intensity of lesions from 0 to 3. The scale does not include subjective symptoms. It is mainly used in clinical studies. Other, less common scales that assess intensity of lesions in AD are POEM (Patient-Oriented Eczema Measure) and IGA (Investigators' Global Assessment) [15].

The basis for AD treatment is a combination of everyday emollient therapy that restores epidermal barrier functions and anti-inflammatory treatment with simultaneous avoidance of contact with allergens and irritating factors (Tables 1 and 2). During periods of disease exacerbations, possible concomitant bacterial, viral or fungal infections should be taken into account, and proper antimicrobial treatment should be applied. If the topical therapy fails to bring improvements, it is recommended to commence phototherapy or systemic treatment [17-19]. 
Table 1. Atopic dermatitis (AD) therapy depending on the intensity of the disease according to SCORAD [17-19] (the next steps in the table complement previous treatment)

\begin{tabular}{|c|c|}
\hline \multirow{6}{*}{$\begin{array}{l}\text { Severe AD } \\
\text { SCORAD > } 50\end{array}$} & Hospitalization \\
\hline & Cyclosporine A (CyA) \\
\hline & Dupilumab \\
\hline & $\begin{array}{l}\text { Methotrexate (MTX), mycophenolate mofetil } \\
\text { (MMF) }\end{array}$ \\
\hline & Azathioprine (AZA) \\
\hline & Oral GCs (maximum for 7 days) \\
\hline \multirow{5}{*}{$\begin{array}{l}\text { Moderate AD } \\
\text { SCORAD } \\
25-50\end{array}$} & Wet dressings \\
\hline & Climate therapy \\
\hline & Psychological/psychiatric interventions \\
\hline & Phototherapy: UVB 311, UVA 1, PUVA (adults) \\
\hline & Proactive therapy \\
\hline \multirow{3}{*}{$\begin{array}{l}\text { Mild AD } \\
\text { SCORAD }<25\end{array}$} & Antiseptics \\
\hline & Topical calcineurin inhibitors \\
\hline & Topical glucocorticosteroids (topical GCs) \\
\hline \multirow{3}{*}{$\begin{array}{l}\text { Primary } \\
\text { therapy }\end{array}$} & Emollient therap \\
\hline & Avoid clinically significant allergens \\
\hline & EDUCATION \\
\hline
\end{tabular}

\section{Primary therapy}

\section{Education}

Lack of co-operation from the patient's side and/or caretaker's is a common reason behind therapy's failure, and thus, educational programs, "schools of atopy", informational leaflets, films, etc. are necessary and significant parts of the treatment. The patient and/or their caretaker should actively participate in the treatment process and have sufficient amount of information regarding the disease. When patients understand the necessity of continual long-term and often multi-specialist treatment, the efficacy is much improved [20-30].

\section{Prophylaxis}

Primary prophylaxis - regards children in the risk group that do not have any disease symptoms. Its aim is to prevent the disease development. Activities associated with primary prophylaxis include prolonged breastfeeding, refraining from smoking during pregnancy, limiting exposure to airborne allergens, mainly dust mites, and application of emollients from the first day of life. Both in children with population risk and in high-risk groups, it is recommended to breastfeed exclusively until the 46 month of life. Breastfeeding allows for limiting the adverse reactions to protein from other species. Moreover, human milk satisfies all nutritional needs, it is a natural and the most balanced food; it contains a number of
Table 2. Primary AD therapy

\begin{tabular}{|c|c|}
\hline \multirow[t]{6}{*}{$\begin{array}{l}\text { Emollient } \\
\text { therapy }\end{array}$} & $\begin{array}{l}\text { Direct application of emollients on the } \\
\text { inflammation is tolerated badly }\end{array}$ \\
\hline & $\begin{array}{l}\text { It is best to use anti-inflammatory drugs } \\
\text { (topical GCs, topical calcineurin inhibitors) }\end{array}$ \\
\hline & Apply at least 2-3 times a day! \\
\hline & $\begin{array}{l}\text { Glycerol is better tolerated than urea and } \\
\text { sodium chloride }\end{array}$ \\
\hline & $\begin{array}{l}\text { Propylene glycol causes irritation easily and } \\
\text { should not be used }\end{array}$ \\
\hline & $\begin{array}{l}\text { It is recommended to use emollients without } \\
\text { protein allergens and haptens }\end{array}$ \\
\hline \multirow[t]{6}{*}{ Skin cleaning } & Gently and thoroughly; mechanically \\
\hline & $\begin{array}{l}\text { Cleaning substances with/without aseptic } \\
\text { substances }\end{array}$ \\
\hline & Proper galenic forms \\
\hline & Physiological pH within the $5.5-6$ range \\
\hline & Fast baths $\leq 5 \mathrm{~min}$, temp. $27-30^{\circ} \mathrm{C}$ \\
\hline & $\begin{array}{l}\text { Adding to the bath } 1 / 2 \text { glass of sodium } \\
\text { hypochlorite eliminates pruritus }\end{array}$ \\
\hline \multirow[t]{4}{*}{ Education } & $\begin{array}{l}\text { Apply proper amounts of emollients } \\
\text { (250-500 g/week) }\end{array}$ \\
\hline & Explain/demonstrate how to use them \\
\hline & $\begin{array}{l}\text { When using different topical drugs, keep } \\
\text { a time gap }\end{array}$ \\
\hline & $\begin{array}{l}\text { At least once a year remind about the } \\
\text { recommendations! }\end{array}$ \\
\hline
\end{tabular}

biologically active substances with immunological value, among others.

Secondary prophylaxis - regards patients, in whom early symptoms of the disease were confirmed. Its aim is to prevent the appearance or exacerbation of symptoms. Emollient therapy (every 4-6 h), avoidance of irritating factors and stress, as well as elimination of allergens responsible for the symptom appearance are recommended. An important part of this prophylaxis types is vocational guidance service.

Tertiary prophylaxis - recommended in patients with full-blown AD in order to decrease the intensity of symptoms and frequency of their recurrence, and to prevent the development of concomitant diseases. This type of prophylaxis includes psychological counselling, and education of patients in order to teach them how to control the symptoms and live with the disease [31].

While taking patient's history, factors that potentially intensify the clinical symptoms should be looked for. Most frequently these include: exposure to airborne and contact allergens, food, various environmental irritating factors (including cigarette smoke and microorganisms), climate factors, stress, and disorders of the hormonal balance $[17,18,32]$. Not every AD-patient reacts to all of 
Table 3. Diagnostics of food allergies in patients with moderate or severe $A D$, in whom symptoms persist despite general treatment and topical therapies [35, 38]

\begin{tabular}{ll}
\hline Age & Tests \\
\hline$<5 \mathrm{y} / \mathrm{o}$ & Cow milk, eggs, wheat, soya, and peanuts \\
\hline$>5 \mathrm{y} / \mathrm{o}$ & $\begin{array}{l}\text { Choosing food for tests should be done } \\
\text { according to the patient's history and } \\
\text { most common allergies in this population: } \\
\text { nuts, shellfish, fish }\end{array}$ \\
\hline $\begin{array}{l}\text { Youths, older age } \\
\text { groups }\end{array}$ & $\begin{array}{l}\text { Concomitant pollen and food allergy } \\
\text { should be taken into account: apples, } \\
\text { celeries, carrots, hazelnuts }\end{array}$ \\
\hline
\end{tabular}

the abovementioned factors. Hypersensitivity to airborne allergens regards most often older children and youths as well as adults [33]. Prophylaxis includes avoidance of clinically significant allergens for a given patients, i.e. pollen (from trees, shrubs, grasses, weeds, grains) during pollination time, allergens associated with dust mites, and contact allergens in case of positive test results and their connection to clinical symptoms [18]. Room ventilation and spending less time in closed spaces are important parts of the therapy.

\section{Elimination diet}

Elimination diet in recommended in patients to determine the etiopathogenetic connections between food intolerance and AD (Table 3) [34]. Eliminating harmful food from patient's diet together with proper pharmacological treatment successfully helps to achieve satisfactory clinical improvements and accelerate the treatment process [33, 35-38]. Individual recommendations with regard to eliminating chosen food from the diet regard only those patients, in whom a negative influence of food intolerance on clinical course of the primary disease was confirmed in an objective way [35].

\section{Elimination diet in AD-patients with concomitant hypersensitivity to food intolerance}

Food that contains harmful allergens needs to be temporarily eliminated from the diet of an AD-patient, and substituted with other non-allergic components with balanced or similar nutritional characteristics [39]. The elimination usually involves one or two nutritionally bivalent foods (most often: cow milk and milk products, eggs, soya, crop plants, fish, and some fruit as well as vegetables).

Validity criteria of the elimination diet are determined by: confirmed concomitant food intolerance and therapeutic efficacy of the diet (remission of skin symptoms or their total remission, minimization of exacerbation and recurrence episodes). Due to the lack of guidelines as to the duration of elimination of harmful food from the diet, the duration needs to be set individually for every patient. When the elimination diet needs to be used long-term, at least once a year a challenge test with the harmful food should be performed on the patient. The test aims at assessing the activity of the food intolerance process. A systematic decrease in this activity is a sign of an AD-patient acquiring immunological tolerance. The process, colloquially called "growing out of a food allergy", results from the used dietetic and pharmacological treatment [39].

In case of severe AD involving a multifood/polyvalent allergy, it may be necessary to eliminate even a couple of foods simultaneously from the sick child's diet. Elimination diet recommended to such patients should be balanced, what is of key importance especially for patients at the developmental age $[39,40]$.

\section{Patients with multifood allergies}

Patients with multifood allergies that are hypersensitive to both cow milk proteins and milk substitute products and some other products than milk constitute a special subgroup of AD-patients. Such patients are introduced to basic formulas that substitute milk in order to balance their diet. They are totally non-allergic to the patient's organism since native protein fraction of cow mild has been substituted with a pool of synthetic amino acids [41].

In case of an infant with AD characterized by moderate-severe and severe course that is fed naturally and in whom appearance of skin lesions has a confirmed causal relation to mother's eating habits, there are indications for temporary elimination of some foods from her diet. In most cases the elimination regards milk and milk products, eggs, earthnuts, nuts, some fruit and vegetables. Composition of the mother's elimination diet and its duration should be supervised by a physician or dietician. It should be remembered that the menu of the breastfeeding mother who uses elimination diet should be enriched with $500 \mathrm{kcal} / \mathrm{day}$, include a substitute of another protein than the one eliminated from the diet, and supplemented with necessary intake of mineral salts (including $1 \mathrm{~g} \mathrm{Ca}^{++} /$day) and vitamins [41].

If a breastfeeding mother is on elimination diet an the condition of her infant fails to improve within 2 weeks, further food elimination needs to be discontinued.

If an infant who is breastfed experiences an anaphylactic reaction that is associated with its mother eating food that allergizes the infant (e.g. milk, eggs, fish, earthnuts), it is an indication to discontinue breastfeeding immediately and give the infant a formula that substitutes milk. Such formulas contain hydrolysed casein fraction or whey protein, and have a decreased ability to allergize as compared with native protein fractions of cow milk [41].

\section{Emollient therapy}

Prophylactic activities include also emollient therapy as it has been confirmed that using it since the birth of 
a child that belongs to an AD risk group significantly decreases the risk of developing AD. Emollients applied from the first day of life in children born in atopic families decrease the risk of developing AD by half [42-44]. A role of emollients in inhibiting the development of allergic march and their common application in prophylaxis for $A D$ group risks and general population is being examined [44-48].

Emollients contain occlusive substances (petroleum jelly, paraffin, mineral oils) that decrease transepidermal water loss (TEWL), moisturizing substances - waterbinding humectants (e.g. urea, sorbitol, glyceryl alcohol, lactic acid), and lipids that seal the epidermal barrier (ceramides, cholesterol, polyenic acids) $[49,50]$. Emollients reduce clinical symptoms of $A D$ in children and adults, while preventing exacerbations and recurrence of atopic eczema, maintain remission state after its induction with topical anti-inflammatory preparations, and visibly decreasing the amount of used topical GCs (steroid sparing effects) [51-62].

It is recommended to use emollients $2-3$ times a day in the amount of minimum $200 \mathrm{~g} /$ week in small children and $500 \mathrm{~g} /$ week in adults $[18,26]$. They should be chosen individually depending on the level of skin dryness, activity during the day and night, and a possible contact allergy. Since some emollients contain ingredients with a variable allergizing potential, it is necessary to read about their composition before use [63]. Applied emollients should not contain heptens that cause contact allergies (odoriferous substances, including essential oils, preservatives such as methylisothiazolinone, and lanoline/wool alcohol), and potentially allergizing proteins, especially in the group of patients who are under the age of 2 [18]. The risk for developing a secondary contact allergy to skin care products and drugs used externally in AD treatment is the highest in severe cases of this disease [64]. It is not recommended to use pure oil, e.g. coconut, as it dries the skin and intensified TEWL. Propylene glycol should not be used in children under 2 , because it can easily irritate gentle epidermis of a child [18]. Due to the fact the urea may cause skin irritation or burning sensation, its concentration in emollients for children and youths should be lower than in preparations used by adults [65].

Currently, it is recommended to use emollients plus enriched with additional active substances such as flavonoids, saponins, or bacterial lysates with Aquaphilus dolomiae, Vitreoscilla filiformis. They show anti-inflammatory effects by inhibiting cytokines (TSLP, IL-18, IL-2, IL-12, IL-17, IFN- $\gamma$, IL-1 $\beta$, TNF- $\alpha$, IL-4) and chemokines (MCP3/CCL7, MDC/CCL22, MIP-3a/CCL20) [18, 38], antipruritic effects [66], they support congenital immunity by activating TLR2, TLR4, TLR5, and natural anti-bacterial peptides (hBD-2, cathelicidin LL-37, psoriasin) [67], inhibit the growth of Staphylococcus aureus, and do not disturb the composition of bacterial flora; they also restore homeostasis of skin microbiome in $\operatorname{AD}[68,69]$, and reconstruct the epidermal barrier.
Opened emollient containers need to be stored at refrigerators; it is recommended to use containers with pumps or a lid that ensures sterility, to avoid direct application of the preparation with hands, and not to share the ointment with others as the risk of contamination with microorganisms increases [18, 19].

Atopic skin requires special care processes (Table 3). Short baths with the use of preparations substituting soap and emollient therapy immediately after the bath (within $3 \mathrm{~min}$ ) are recommended [18, 19].

In case of inflammation, topical anti-inflammatory therapy should be applied first, as even the best emollients may irritate the inflamed skin, and discourage the patients from their further use [18].

\section{Topical anti-inflammatory therapy \\ Topical glucocorticosteroids}

Topical glucocorticosteroids (topical GCs) have constituted the basis for AD treatment for over 50 years. Together with emollients they ensure excellent therapeutic effects. Due to skin dryness, topical GCs in the form of ointment are preferred, except for oozing lesions - in the case of these lighter forms should be applied (lotion, aerosol, cream). Application of topical GCs decreases skin colonization with $S$. aureus. During exacerbation periods, it is recommended to use topical GCs with a moderate effect in the evening, because they also have anti-pruritic qualities apart from providing anti-inflammatory effects [17-19].

Due to high efficacy obtained within a short time since the therapy introduction and low price, topical GCs are often abused. In children, these drugs should be used carefully and under close dermatological supervision, because children have a different skin structure. The choice of a preparation should be associated with disease intensity, site of lesions, age of the patients, medium in which the active substance is suspended, and drug registration (Table 4). According to the Summary Product Characteristics (SPC), fluticasone propionate, alclometasone, and betamethasone valerate are allowed for patients above the age of 1 , whereas hydrocortisone butyrate, mometasone furoate, and methylprednisolone aceponate are allowed for patients above the age of 2 . Other topical GCs may be used above the age of 6 or 12 .

Table 4. Age of use topical GCs according to the SPC

\begin{tabular}{lc}
\hline Topical GCs & Age from the SPC \\
\hline Fluticasone propionate & $>1 \mathrm{y} / \mathrm{o}$ \\
\hline Alclometasone & $>2 \mathrm{y} / \mathrm{o}$ \\
\hline Betamethasone valerate & \\
\hline Hydrocortisone butyrate & \\
\hline Mometasone furoate & \\
\hline
\end{tabular}




\section{Adverse reactions of preparations containing topical glucocorticosteroids}

Long-term use of topical GCs, especially from the groups that have potent effects, is often associated with adverse reactions such as: skin atrophy, permanent vasodilation (telangiectasias), stretch marks, hypertrichosis, dyspigmentation, perioral dermatitis, bacterial and/or fungal superinfections, cataracts, glaucoma, withdrawal effect (exacerbation of skin lesions after drug discontinuation), and tachyphylaxis (gradual decrease in drug efficacy as the drug is used long-term). Paradoxically, a contact allergy may also develop. Topical application of potent topical GCs on large areas in children, and infants in particular, may cause general adverse reactions: inhibition of the hypothalamic-pituitary-adrenal axis, growth failure, and osteoporosis. Fear of adverse reactions is the most common reason for non-observance of physician's recommendation by patients, and in case of children - by their parents, what in turn leads to lack of treatment efficacy. To avoid potential adverse reactions, it is recommended to use a so-called intermittent therapy that is based on using topical GCs only $2-3$ days a week and emollients alternately. Topical GCs should be used according to the manufacturer's recommendations, because its frequent use does not increase the treatment efficacy - it rather increases the risk for adverse reactions. Additionally, a FTU (finger tip unit) rule may help in safe application of these drugs [17, 70-73].

\section{Steroid phobia}

More than half of AD-patients fear the use of topical GCs, what has been revealed by studies conducted among the patients. Furthermore, it was showed that patients have little knowledge about the therapeutic potential of topical GCs and their adverse reactions, and the main source of knowledge for patients is the Internet. The problem of steroid phobia is not limited to Poland, but regards the entire Europe and is a reason behind inefficacy of topical AD therapies. Proper education of patients and interpersonal relations between patients and physicians that are based on mutual trust, could improve the efficacy of AD treatment [74]. Patients with steroid phobia should be identified and educated by physicians and pharmacists, what might improve observance of recommendations [18].

\section{Topical calcineurin inhibitors}

Topical calcineurin inhibitors - tacrolimus and pimecrolimus - inhibit activation of T lymphocytes and release of inflammatory cytokines. Pimecrolimus as a 1\% cream is recommended as the first-line treatment in mild $\mathrm{AD}$, and its clinical profile suggested that it may be also considered as a treatment of choice in mild and moderate AD, both in children and adults, especially within sensitive skin regions [75]. Tacrolimus as $0.03 \%$ and $0.1 \%$ ointment is recommended in moderate and severe atopic eczema. Tacrolimus, as compared with pimecrolimus, shows faster and more potent effects, and clinical improvements after its use are visible already during the first week of treatment. These preparations are applied twice a day till inflammation disappears, with special indication for sensitive skin regions such as bends, face, neck, intertriginous areas, and the skin of genital organs both in adults and children. Patients treated with topical calcineurin inhibitors should have effective sun protection recommended [18]. As opposed to topical GCS, topical calcineurin inhibitors do not inhibit collagen synthesis, do not cause epidermal thinning, vasodilation, and do not damage the skin barrier. The cause neither cataracts nor glaucoma [18]. The most common adverse reaction associated with the use of topical calcineurin inhibitors is connected to neuropeptide release - a burning sensations and skin reddening that usually lasts about $30 \mathrm{~min}$ at the site of application and disappears after several days $[17,18,75,76]$.

Based on existing analyses of treatment results, it is believed that limits regarding the use of pimecrolimus in infants are unfounded. It is suggested to prepare new recommendations and warning on labels of topical calcineurin inhibitors [77]. Tacrolimus as a $0.1 \%$ ointment has a more potent effect than pimecrolimus as a cream. Topical calcineurin inhibitors show a significant therapeutic effect in long- and short-term treatment of AD [18].

Treatment of acute inflammatory lesions should include topical GCs initially, and then topical calcineurin inhibitors [18]. Topical GCs are also recommended to control pruritus at an initial stage of AD exacerbation; then, until the symptoms disappear - topical calcineurin inhibitors [19]. Polidocanol may be used topically in order to decrease pruritus; furthermore, UVB and UVA1 phototherapy is recommended $[18,19]$.

\section{Proactive therapy}

A proactive therapy is a long-term intermittent therapy involving topical anti-inflammatory preparations used at sites where eczema used to appear, after its remission. Studies involving tacrolimus in proactive therapies lasted up to 12 months. A decrease in frequency of $A D$ exacerbations, extension of the period till the first disease exacerbation, improvement in patients' quality of life, and decrease in $A D$ treatment costs were showed among patients that used proactive therapies with tacrolimus. A proactive therapy used twice a week for a longer period of time may help reduce disease recurrences $[18,78,79]$.

\section{Wet dressings}

A so-called "wet dressings" therapy may be used in children aged from 6 months to 10 years with severe AD (SCORAD above 50 points). This method uses two layers of dressings: the first wet one is placed directly on 
the skin with applied emollient or $0.05 \%$ fluticasone propionate or mometasone furoate that is properly diluted $(1: 3,1: 9,1: 19)$, and then the second dry layer of a superficial dressing. The therapy lasts from 3 to 14 days and is conducted under strict supervision of a physician, with the use of diluted topical GCs, most often in the hospital, and requires monitoring of the cortisol level in the mornings, because its adverse reaction may include suppression of adrenal glands [80].

Wet dressings have a cooling, anti-inflammatory, and anti-pruritic effects. They create a mechanical barrier against external environmental factors and protect the child from scratching, while potentially decrease the amount of used topical GCS. On the other hand, they cause an increased absorption of topical GCs, risk for developing bacterial infections, and skin atrophy. Moreover, this form of therapy requires training of caretakers or patients, what increases its cost [81].

Treatment by means of "wet dressings" is a safe therapy in severe and recurrent AD cases; it is tolerated well by children and significantly increases their quality of life [82]. Spectacular effects observed already after a week of treatment with this method are highlighted, however, in some cases within 4 weeks from the treatment discontinuation a considerable worsening of AD may occur; hence, studies on proactive application of wet dressings are conducted [82]. Studies' results encourage to use this method, however, further controlled standardized clinical studies are need to recommend it [83].

\section{Antimicrobial treatment}

Skin of AD-patients does not have a natural microbiological diversity $[84,85]$. During disease exacerbation periods, bacterial flora of AD-patients' skin is dominated by S. aureus [85]. Every exacerbation of $A D$ symptoms may be associated with an infection, most often staphylococcal, and eradication of S. aureus improves the disease course [86]. Studies indicate therapeutic efficacy of octenidine, chlorhexidine, mupirocin, fusidic acid, and retapamulin against S. aureus. Usage of antiseptic baths with addition of sodium hypochlorite decreases the number of bacteria, reduces pruritus, and improves patient's clinical condi- tion [18]. It is not recommended to use topical antibiotics chronically as resistance to antibiotics may develop [18, $19,86-89]$. A justification for the use of oral antibiotics is exacerbation of $A D$ with clinical signs of bacterial infection. In other cases, treatment involving oral antibiotics is not recommended [17-19, 90, 91]. Short cycles of oral antibiotics, e.g. cephalosporin, may be considered in patients with clinical signs of an infection with $S$. aureus $[18,19]$. Due to a disordered profile of antibacterial peptides in $A D$, achieving a continual skin decolonization is practically impossible [88]. Anti-inflammatory treatment (topical calcineurin inhibitors, topical GCS, UV) decrease colonization with S. aureus in AD [17].

Atopic skin infection with herpes simplex virus (HSV) often manifests itself as eczema herpeticum (Kaposi varicelliform eruption; eczema herpetiformis - EH) and requires immediate systemic antiviral treatment with acyclovir $[18,92]$. AD-patients with lesions found on the head, face, and neck, also suffer from concomitant infection with yeasts - Malassezia sp., which disappears after the use of topical antifungal treatment (ketoconazole or ciclopirox olamine) [18, 93-95].

\section{Phototherapy}

Phototherapy may be used as monotherapy or in combination with topical GCs (Table 5). Narrow-band UVB (NB-UVB - $311 \mathrm{~nm}$ ) is an effective and safe method in the treatment of moderate and severe $A D$ in school children and adults [96]. Furthermore, moderate doses of UVA1 (340-400 nm) are recommended for adults with AD; PUVA may be used in selected cases [18, 19, 97, 98]. A limitation of phototherapy is its little availability. Rare adverse reactions include: erythema and tenderness after radiation, pruritus, burns and post-sun skin damage, skin cancers, melanoma, lentigines, photosensitivity reactions (mainly polymorphous light eruptions), folliculitis, photoonycholysis, HSV reactivation, excessive facial hair growth, and cataracts [97].

\section{Conflict of interest}

The authors declare no conflict of interest.

Table 5. Phototherapy in $\operatorname{AD}[96,97]$

\begin{tabular}{|c|c|}
\hline $\begin{array}{l}\text { Narrow-band UVB } \\
\text { (NB-UVB) }\end{array}$ & 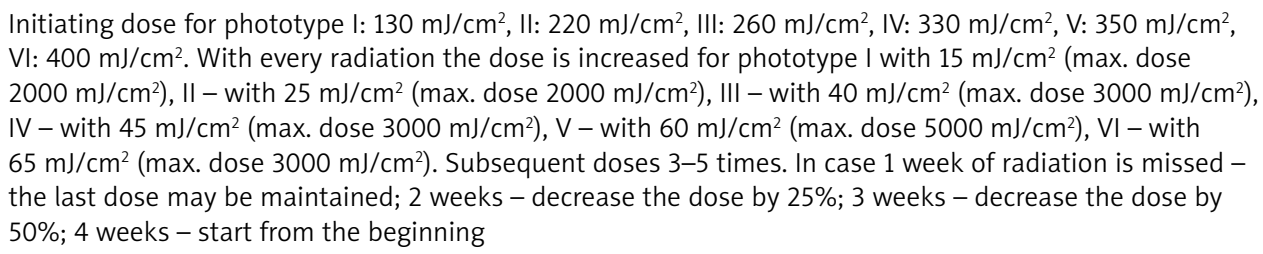 \\
\hline Adjuvant therapy & Disappearance of lesions > 95\%: last dose once/week for 4 weeks, then 1 dose decreased by $25 \%$ every \\
\hline NB-UVB method & 2 weeks - for 4 weeks, then once/month $50 \%$ of the highest dose \\
\hline
\end{tabular}




\section{References}

1. Schlapbach C, Simon D. Update on skin allergy. Allergy 2014; 69: 1517-81.

2. Garmhausen D, Hagemann T, Bieber T, et al. Characterization of different courses of atopic dermatitis in adolescent and adult patients. Allergy 2013; 68: 498-506.

3. Grize L, Gassner M, Wüthrich B, Bringolf-Isler B. Trends in prevalence of asthma, allergic rhinitis and atopic dermatitis in 5-7-year old Swiss children from 1992 to 2001. Allergy 2006; 61: 556-62.

4. Weber AS. Haidinger G. The prevalence of atopic dermatitis in children is influenced by their parents' education: results of two cross-sectional studies conducted in Upper Austria. Pediatr Allergy Immunol 2010; 21: 1028-35.

5. Kowalska-Oledzka E, Czarnecka M, Baran A. Epidemiology of atopic dermatitis in Europe. J Drug Assessment 2019; 8: 126-8.

6. Silverberg J. Adult-onset atopic dermatitis. J Allergy Clin Immunol Pract 2019; 7: 28-33.

7. Kruszewski J. Definicja, epidemiologia i genetyka atopowego zapalenia skóry. In: Atopowe zapalenie skóry u dzieci i dorosłych. Stanowisko Panelu Ekspertów Polskiego Towarzystwa Alergologicznego. Gliński W, Kruszewski J (eds.). Medycyna Praktyczna, Warsaw 2012; 11-3.

8. Cipriani F. Autoimmune diseases involving skin and intestinal mucosa are more frequent in adolescents and young adults suffering from atopic dermatitis. J Dermatol 2017; 44: 1341-8.

9. Silverberg JI. Association between adult atopic dermatitis, cardiovascular disease, and increased heart attacks in three population-based studies. Allergy 2015; 70: 1300-8.

10. Silverberg JI. Selected comorbidities of atopic dermatitis: atopy, neuropsychiatric, and musculoskeletal disorders. Clin Dermatol 2017; 35: 360-6.

11. Czarnobilska E, Obtulowicz K, Dyga W, Śpiewak R. The most important contact sensitizers in Polish children and adolescents with atopy and chronic recurrent eczema as detected with the extended European Baseline Series. Pediatr Allergy Immunol 2011; 22: 252-6.

12. Czarnobilska E, Obtulowicz K, Dyga W, Śpiewak R. A half of schoolchildren with 'ISAAC eczema' are ill with allergic contact dermatitis. J Eur Acad Dermatol Venereol 2011; 25: 1104-7.

13. Bozek A, Reich A. Metody oceny nasilenia atopowego zapalenia skóry. Przegl Dermatol 2016; 103: 479-85.

14. Schmitt J, Langan S, Deckert S, et al. Assessment of clinical signs of atopic dermatitis: a systematic review and recommendation. J Allergy Clin Immunol 2013; 132: 1337-47.

15. Coutanceau C, Stalder JF. Analysis of correlations between patient-oriented SCORAD (PO-SCORAD) and other assessment scores of atopic dermatitis severity and quality of life. Dermatology 2014; 229: 248-55.

16. Van Os-Medendrop H, Koffijberg H, Eland-de Kok PC, et al. E-health in caring for patients with atopic dermatitis: a randomized controlled cost-effectiveness study of internetguided monitoring and online self-management training. Br J Dermatol 2012; 166: 1060-8.

17. Wollenberg A, Oranje A, Deleuran M, et al. ETFAD/EADV Eczema task force 2015 position paper on diagnosis and treatment of atopic dermatitis in adult and paediatric patients. J Eur Acad Dermatol Venereol 2016; 30: 729-47.

18. Wollenberg A, Barbarot S, Bieber T, et al. Consensus-based European guidelines for treatment of atopic eczema (atopic dermatitis) in adults and children: part I. J Eur Acad Dermatol Venereol 2018; 32: 657-82.
19. Wollenberg A, Barbarot S, Bieber T, et al. Consensus-based European guidelines for treatment of atopic eczema (atopic dermatitis) in adults and children: part II. J Eur Acad Dermatol Venereol 2018; 32: 850-78.

20.Lewis-Jones S. Quality of life and childhood atopic dermatitis: the misery of living with childhood eczema. Int I Clin Pract 2006; 60: 984-92.

21. Carroll CL, Balkrishnan R, Feldman SR, et al. The burden of atopic dermatitis: impact on the patient, family, and society. Pediatr Dermatol 2005; 22: 192-9.

22. Eller E, Kjaer HF, Høst A, et al. Development of atopic dermatitis in the DARC birth cohort. Pedriatr Allergy Immunol 2010; 21: 307-14.

23. Bozek A, Jarzab J. Epidemiology of IgE-dependent allergic diseases in elderly patients in Poland. Am J Rhinol Allergy 2013; 27: 140-5.

24. Silverberg JI, Hanifin JM. Adult eczema prevalence and associations with asthma and other health and demographic factors: a US population-based study. J Allergy Clin Immunol 2013; 132: 1132-8.

25. Ring J, Alomar A, Bieber T, et al. Guidelines for treatment of atopic eczema (atopic dermatitis). Part II. J J Eur Acad Dermatol Venereol 2012; 26: 1176-93.

26. Lebwohl MG, Del Rosso JQ, Abramovits W, et al. Pathways to managing atopic dermatitis: consensus from the experts. J Clin Aesthet Dermatol 2013; 6 (7 Suppl): S2-18.

27. Mancini AJ, Paller AS, Simpson EL, et al. Improving the patientclinician and parent-clinician partnership in atopic dermatitis management. Semin Cutan Med Surg 2012; 31 (3 Suppl): S23-77.

28. Kupfer J, Gieler U, Diepgen TL, et al. Structured education program improves the coping with atopic dermatitis in children and their parents-a multicenter, randomized controlled trial. J Psychosom Res 2010; 68: 353-8.

29. Takaoka R, Aoki V. Education of patients with atopic dermatitis and their caregivers. Pediatric Allergy Immunol Pulmonol 2016; 29: 160-3.

30. Weber MB, Lorenzini D, Reinehr CP, Lovato B. Assessment of the quality of life of pediatric patients at a center of excellence in dermatology in southern Brazil. An Bras Dermatol 2012; 87: 697-702.

31. Hamelmann E, Hertz $U$, Holt $P$, et al. New visions for basic research and primary prevention of pediatric allergy: an IPAC summary and futures trends. Pediatr Allergy Clin Immunol 2008; 19 (suppl. 19): 4-6.

32. Leung DYM, Bieber T. Atopic dermatitis. Lancet 2003; 361: 151-60.

33. Cudowska B, Kaczmarski M. Udział reakcji krzyżowych w kształtowaniu wielonarządowych objawów klinicznych u dzieci z alergią pokarmową i wziewną. Pediatr Pol 2001; 76: 761-6.

34. Werfel T, Ballimer-Weber B, Eigenmann PA, et al. Rola nadwrażliwości pokarmowej w atopowym zapaleniu skóry. Stanowisko EAACI i GA2LEN. Allergy 2007; 62: 723-8.

35. Boyce J, Assa'ad A, Burks W, et al. Guidelines for the diagnosis and management of food allergy in the United States. Report of the NIAID-Sponsored Expert Panel. J Allergy Clin Immunol 2010; 126 (6 Suppl): S1-58.

36. Sicherer S, Sampson HA. Food hypersensitivity and atopic dermatitis: pathophysiology, epidemiology, diagnosis and management. J Allergy Clin Immunol 1999; 104: 114-22.

37. Sampson HA. Update on food allergy. J Allergy Clin Immunol 2004; 113: 803-5. 
38. Werfel T, Breuer K. Role of food allergy in atopic dermatitis. Curr Opin Allergy Clin Immunol 2004; 4: 379-95.

39. Kaczmarski M, Wasilewska J, Jarocka-Cyrta E, et al. Polish statement on food allergy in children and adolescents. Post Dermatol Alergol 2011; 28: 331-67.

40. Kaczmarski M, Żur E, Cudowska B, Wasilewska J. Alergia pokarmowa w wieku dziecięcym - aktualny problem kliniczny, diagnostyczny i leczniczy. Gastroenterol Prakt 2012; 4: 23-30.

41. Kaczmarski M. Leczenie dietetyczne chorych z atopowym zapaleniem skóry i wspótistniejącą alergią pokarmową. [In:] Atopowe zapalenie skóry. Poradnik lekarza praktyka. Nowicki RJ (ed.). Oficyna Wydawnicza Medical Education, Warsaw 2017; 133-152.

42.Simpson EL, Chalmers JR, Hanifin JM, et al. Emollient enhancement of the skin barrier from birth offers effective atopic dermatitis prevention. J Allergy Clin Immunol 2014; 134: 818-23.

43. Horimukai K, Morita K, Narita M, et al. Application of moisturizer to neonates prevents development of atopic dermatitis. J Allergy Clin Immunol 2014; 134: 824-30.

44. Lowe AJ, Leung DYM, Tang MLK, et al. The skin as a target for prevention of the atopic march. Ann Allergy Asthma Immunol 2018; 120: 145-51.

45. Simpson EL, Berry TM, Brown PA, Hanifin JM. A pilot study of emollient therapy for the primary prevention of atopic dermatitis. J Am Acad Dermatol 2010; 63: 587-93.

46. Correa CM, Nebus J. Management of patients with atopic dermatitis: the role of emollient therapy. Dermatol Res Pract 2012; 2012: 836931

47. Lødrup Carlsen KC, Rehbinder EM, Skjerven HO, et al. Preventing atopic dermatitis and ALLergies in children - the PreventADALL study. Allergy 2018; 73: 2063-70.

48. Lowe A, Su J, Tang M, et al. PEBBLES study protocol: a randomised controlled trial to prevent atopic dermatitis, food allergy and sensitisation in infants with a family history of allergic disease using a skin barrier improvement strategy. BMJ Open 2019; 9: e024594.

49. Narbutt J. Lesiak A. I-modulia ${ }^{\circledR}$ w badaniach klinicznych zastosowanie emolientów $u$ chorych na atopowe zapalenie skóry. Forum Dermatologicum 2016; 2: 139-43.

50. Welz-Kubiak K, Reich A. Znaczenie emolientów w codziennej pielęgnacji skóry. Forum Dermatologiczne 2016; 2: 20-3.

51. Mengeaud V, Phulpin C, Bacquey A, et al. An innovative oatbased sterile emollient cream in the maintenance therapy of childhood atopic dermatitis. Pediatr Dermatol 2015; 32: 208-15.

52. Akerstrom U, Reitamo S, Langeland T, et al. Comparison of moisturizing creams for the prevention of atopic dermatitis relapse: a randomized double-blind controlled multicentre clinical trial. Acta Derm Venereol 2015; 95: 587-92.

53. Breternitz M, Kowatzki D, Langenauer M, et al. Placebocontrolled, double-blind, randomized, prospective study of a glycerol-based emollient on eczematous skin in atopic dermatitis: biophysical and clinical evaluation. Skin Pharmacol Physiol 2008; 21: 39-45.

54. Eichenfield LF, Tom WL, Berger TG, et al. Guidelines of care for the management of atopic dermatitis: section 2. Management and treatment of atopic dermatitis with topical therapies. J Am Acad Dermatol 2014; 71: 116-32.

55. Angelova-Fischer I, Neufang G, Jung K, et al. A randomized, investigator-blinded efficacy assessment study of standalone emollient use in mild to moderately severe atopic dermatitis flares. J Eur Acad Dermatol Venereol 2014; 28 (Suppl 3): 9-15.
56. Boralevi F, Saint Aroman M, Delarue A, et al. Long-term emollient therapy improves xerosis in children with atopic dermatitis. J Eur Acad Dermatol Venereol 2014; 28: 1456-62.

57. Czarnowicki T. Malajian D, Khattri S, et al. Petrolatum: barrier repair and antimicrobial responses underlying this “inert”moisturizer. J Allergy Clin Immunol 2016; 137: 1091102.

58. Korting HC, Braun Falco O. Efficacy and tolerability of pale sulfonated shale oil cream $4 \%$ in the treatment of mild to moderate atopic eczema in children: a multicentre, randomized vehicle-controlled trial. J Eur Acad Dermatol Venereol 2010; 24: 1176-82.

59. Szczepanowska J, Reich A, Szepietowski JC. Emollients improve treatment results with topical corticosteroids in childhood atopic dermatitis: a randomized comparative study. Pediatr Allergy Immunol 2008; 19: 614-61.

60.Grimalt R, Mengeaud V, Cambazard F. The steroid-sparing effect of an emollient therapy in infants with atopic dermatitis: a randomized controlled study. Dermatology 2007; 214: 61-73.

61. Msika P, De Belilovsky C, Piccardi N, et al. New emollient with topical corticosteroid-sparing effect in treatment of childhood atopic dermatitis: SCORAD and quality of life improvement. Pediatr Dermatol 2008; 25: 606-12.

62. Eberlein B, Eicke C, Reinhardt HW, Ring J. Adjuvant treatment of atopic eczema: assessment of an emollient containing $\mathrm{N}$ palmitoylethanolamine (ATOPA study). J Eur Acad Dermatol Venereol 2008; 22: 73-82.

63. Kordus K, Śpiewak R. Emolienty z apteki - pomoc czy zagrożenie dla chorych na wyprysk? Alergia Astma Immunologia 2012; 17: 147-53.

64. Mailhol C, Lauwers-Cances V, Rancé F, et al. Prevalence and risk factors for allergic contact dermatitis to topical treatment in atopic dermatitis: a study in 641 children. Allergy 2009; 64: 801-6.

65. Wollenberg A, Szepietowski J, Taieb A, Ring J. Corrigendum: consensus-based European guidelines for treatment of atopic eczema (atopic dermatitis) in adults and children: part I. J Eur Acad Dermatol Venereol 2019; 33: 1436.

66. Fostini AC, Victor Georgescu V, Decoster CJ, Girolomoni G. A cream based on Aquaphilus dolomiae extracts alleviates non-histaminergic pruritus in humans. Eur J Dermatol 2017; 27: 317-8.

67. Aries MF, Hernandez-Pigeon H, Vaissière C, et al. Anti-inflammatory and immunomodulatory effects of Aquaphilus dolomiae extract on in vitro models. Clin Cosmet Investig Dermatol 2016; 9: 421-43.

68. Bianchi P, Theunis J, Casas C, et al. Effects of a new emollient-based treatment on skin microflora balance and barrier function in children with mild atopic dermatitis. Pediatr Dermatol 2016; 33: 165-71.

69. Martin H, Laborel-Préneron E, Fraysse F, et al. Aquaphilus dolomiae extract counteracts the effects of cutaneous S. aureus secretome isolated from atopic children on CD4+ T cell activation. Pharm Biol 2016; 54: 2782-5.

70. Schmid-Grendelmeier P, Simon D, Simon HU, et al. Epidemiology, clinical features, and immunology of the intrinsic (non-IgE-mediated) type of atopic dermatitis (constitutional dermatitis). Allergy 2001; 56; 841-9.

71. Akdis CA, Akdis M, Biber T, et al. Diagnosis and treatment of atopic dermatitis in children and adults. European Academy of Allergology and Clinical immunology/PRACTALL consensus report. Allergy 2006; 61: 969-87. 
72. Hanifin JM, Cooper KD, Ho VC, et al. Guidelines of care for atopic dermatitis. J Am Acad Dermatol 2004; 50: 391-404.

73. Green C, Colquitt JL, Kirby J, Davidson P. Topical corticosteroids for atopic eczema: clinical and cost effectiveness of once-daily vs. more frequent use. Br J Dermatol 2005; 152: 130-41.

74. Jenerowicz D, Czarnecka-Operacz M, Silny W. Corticosteroid phobia in patients with atopic dermatitis. Wiad Lek 2005; 58: 607-15.

75. Luger T, de Raeve L, Gelmetti C, et al. Recommendations for pimecrolimus $1 \%$ cream in the treatment of mild-to-moderate atopic dermatitis: from medical needs to a new treatment algorithm. Eur J Dermatol 2013; 23: 758-66.

76.Schmitt J, von Kobyletzki L, Svensson A, Apfelbacher C. Efficacy and tolerability of proactive treatment with topical corticosteroids and calcineurin inhibitors for atopic eczema: systematic review and meta-analysis of randomized controlled trials. Br J Dermatol 2011; 164: 415-28.

77. Luger T, Boguniewicz M, Carr W. Pimecrolimus in atopic dermatitis: consensus on safety and the need to allow use in infants. Pediatr Allergy Immunol 2015; 26: 306-15.

78. Wollenberg A, Bieber T. Proactive therapy of atopic dermatitis - an emerging concept. Allergy 2009; 64; 276-8.

79. Wollenberg A, Reiner F, Kroth J, Ruzicka T. Proactive therapy of atopic eczema - an evidence-based concept with a behavioral background. J Dtsch Dermatol Ges 2009; 7: 117-21.

80.Arjan CA, Devillers A, Oranje AP. Wet-wrap treatment in children with atopic dermatitis: a practical guideline. Pediatr Dermatol 2012; 29: 24-7.

81. Devillers ACA, de Waard van der Speck FB, Mulder PGH, Oranje AP. Treatment of refractory atopic dermatitis using 'wet-wrap' dressings and diluted corticosteroids: results of standardized treatment in both children and adults. Dermatology 2002; 204: 50-5.

82. Oranje AP, Devillers AC, Kunz B, et al. Treatment of patients with atopic dermatitis. Using wet-wrap-dressings with diluted steroids and/or emollients. An export-panel's opinion and review of the literature. J Eur Acad Dermatol Venereol 2006; 20: 1277-86

83. Braham SJ, Pugashetti R, Koo J, Maibach HI. Occlusive therapy in atopic dermatitis: overview. J Dermatolog Treat 2010; 21: 62-72.

84. Kong HH, Oh J, Deming C, et al. Temporal shifts in the skin microbiome associated with disease flares and treatment in children with atopic dermatitis. Genome Res 2012; 22: 850-9.

85. Kong HH, Segre JA. Skin microbiome: looking back to move forward. J Invest Dermatol 2012; 132: 933-9.

86. Huang JT, Abrams M, Tlougan B, et al. Treatment of Staphylococcus aureus colonization in atopic dermatitis decreases disease severity. Pediatrics 2009; 123: e808-14.

87. Kircik LH. Efficacy and tolerability of retapamulin $1 \%$ ointment for the treatment of infected atopic dermatitis: a pilot study. J Drugs Dermatol 2012; 11: 858-60.

88. Alsterholm M, Flytstrom I, Bergbrant IM, Faergemann J. Fusidic acid-resistant Staphylococcus aureus in impetigo contagiosa and secondarily infected atopic dermatitis. Acta Derm Venereol 2010; 90: 52-7.

89. Thum D, Seidl HP, Hein R, et al. Current resistance patterns of Staphylococcus aureus towards topical antibotics and relevant antiseptics in patients with atopic dermatitis and impetigo. J Dtsch Dermatol Ges 2013; 11; 875-8.

90.Cardona ID, Cho SH, Leung DY. Role of bacterial superantigens in atopic dermatitis: implications for future therapeutic strategies. Am J Clin Dermatol 2006; 7: 273-9.
91. Ewing C, Ashcroft C, Gibbs A. Flucloxacillin in the treatment of atopic dermatitis. Br J Dermatol 1998; 138: 1022-9.

92. Hung SH, Lin YT, Chu CY, et al. Staphylococcus colonization in atopic dermatitis treated with fluticasone or tacrolimus with or without antibiotics. Ann Allergy Asthma Immunol 2007; 98: 51-6.

93. Lintu P, Savolainen J, Kortekangas-Savolainen O. Kalimo K. Systemic ketoconazole is an effective treatment of atopic dermatitis with IgE-mediated hypersensitivity to yeasts. Allergy 2001; 56: 512-7.

94. Mayser P, Kupfer J, Nemetz D, et al. Treatment of head and neck dermatitis with ciclopiroxolamine cream - results of a double-blind, placebo-controlled study. Skin Pharmacol Physiol 2006; 19: 153-8.

95. Schnopp C, Ring J, Mempel M. The role of antibacterial therapy in atopic eczema. Expert Opin Pharmacother 2010; 11: 929-36.

96.Crall CS, Rork JF, Delano S, Huang JT. Phototherapy in children: considerations and indications. Clin Dermatol 2016; 34: 633-9.

97. Sidbury R, Davis DM, Cohen DE, et al. Guideline of care for the management of atopic dermatitis. Section 3. Management and treatment with phototherapy and systemic agents. J Am Acad Dermatol 2014; 71: 327-49. 